\title{
Keçiboynuzu unu (Ceratonia siliqua L.) kullanımının eriştelerin fiziksel, kimyasal ve duyusal özelliklerine etkisi
}

\section{Effects of carob flour (Ceratonia siliqua L.) on physical, chemical and sensory properties of noodles}

\author{
ilkay YILMAZ1 iD, Burçin Başarık ŞEN 2*iD \\ ${ }^{1}$ Başkent Üniversitesi, Güzel Sanatlar Tasarım ve Mimarlık Fakültesi, Gastronomi ve Mutfak Sanatları Bölümü, Ankara, Türkiye \\ ${ }^{2}$ istanbul Ayvansaray Üniversitesi, Lisansüstü Eğitim Enstitüsü, Gastronomi ve Mutfak Sanatları Bölümü, İstanbul, Türkiye,
}

${ }^{1}$ https://orcid.org/0000-0001-5938-3112; ${ }^{2}$ https://orcid.org/0000-0001-8618-7248

To cite this article:

Yılmaz, i. \& Şen, B.B. (2021). Keçiboynuzu unu (Ceratonia siliqua L.) kullanımının eriştelerin fiziksel, kimyasal ve duyusal özelliklerine etkisi. Harran Tarım ve Gıda Bilimleri Dergisi, 25(3):

DOI: $10.29050 /$ harranziraat.864946

*Address for Correspondence: Burçin Başarık ŞEN e-mail:

burcin.basarik@adu.edu.tr

Received Date:

20.01.2021

Accepted Date:

28.07.2021

(C) Copyright 2018 by Harran University Faculty of Agriculture. Available on-line at www.dergipark.gov.tr/harranziraat

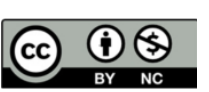

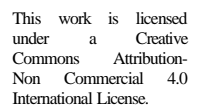

öz

$\mathrm{Bu}$ araştırmada, eriştelerin pişme, fiziksel, kimyasal ve duyusal özelliklerini geliştirmek amacıyla formülasyonda keçiboynuzu unu kullanım imkanı araştırılmıştır. Keçiboynuzu unu (KU) erişte formülasyonuna un ağırlığı üzerinden $\% 0, \% 5, \% 7.5, \% 10$ oranlarında ilave edilmiştir. Erişte örneklerinin pişme sürelerinde önemli $(p=0.024)$ bir fark bulunmazken, hacim artışı (\%) değerlerinde keçiboynuzu unu oranı arttıkça artış gözlemlenmiştir. Ağırlık artışı (\%), suya geçen madde (SGM) (\%) ve toplam organik madde (TOM) (\%) değerlerinde keçiboynuzu oranı arttıkça anlamlı bir azalış $(p<0.05)$ gözlemlenmiştir. Kontrol örneği ve \%5 KU ilaveli örnekte nem miktarlarında anlamlı farklılık bulunmuş $(p=0.015)$ ve keçiboynuzu unu miktarı artıkça artış gözlemlenmiştir. Keçiboynuzu unu ilavesi erişte örneklerinin kül (\%) miktarı ve protein (\%) miktarında da anlamlı farklılıklara neden olmuş ( $p=0.015)$ ve ilave oranı arttıkça artışlar gözlenmiştir. Keçiboynuzu unu ilavesi ile eriştelere ait $L^{*}, a^{*}$ ve $b^{*}$ değerlerinin her birinde önemli $(p<0.05)$ bir azalış saptanmıştır. Eriştelere uygulanan duyusal analizler sonucunda \%10 keçiboynuzu unu katkılı eriştelerde genel beğeni, lezzet ve koku açısından diğer eriştelere göre anlamlı bir artış gözlenmiştir. Duyusal olarak en beğenilen erişte \%10 keçiboynuzu unu katkılı erişte olmuştur. Tüm sonuçlar değerlendirildiğinde keçiboynuzu ununun \%10 orana kadar erişte formülasyonuna ilave edilmek suretiyle daha besleyici bir ürün üretiminin mümkün olduğu sonucuna varılmıştır.

Anahtar Kelimeler: Erişte, Keçiboynuzu Unu, Fonksiyonel Gıda

\section{ABSTRACT}

In this research, the possibility of using carob flour in the formulation was investigated in order to improve the cooking, physical, chemical and sensory properties of noodles. Carob flour (CF) was added to the noodle formulation in the proportion of $0 \%, 5 \%, 7.5 \%, 10 \%$ by weight of the flour. While there was no significant difference $(p=0.024)$ in the cooking times of the noodle samples, $t$ was observed that volume (\%) values increased while the changing of carob flavour proportion in the ratio. A significant decrease was observed $(p<0.05)$ as the carob ratio increased in weight gain (\%), substance passing into water (SGM) (\%) and total organic matter (TOM) (\%) values. A significant difference was found in the moisture content of the control sample and the sample with $5 \% \mathrm{KU}(p=0.015)$ and an increase was observed as the amount of carob flour increased. The addition of carob flour caused significant differences in the amount of ash (\%) and protein (\%) of the noodle samples $(p=0.015)$ and increases were observed as the addition rate rised. A significant $(p<0.05)$ decrease was found in each of the $L$, $a$ and $b$ values of noodles with the addition of carob flour. As a result of the sensory analysis applied to the noodles, a significant increase was observed in the noodles with $10 \%$ carob flour 
compared to the other noodles in terms of general taste, taste and smell. The most favored noodles for the senses have been the noodles with $10 \%$ carob flour. When all results are evaluated, it is concluded that it is possible to produce a more nutritious product by adding carob flour up to $10 \%$ to the noodle formulation.

Key Words: Noodles, Carob Flour, Functional Food

\section{Giriş}

İnsanlar yaşamlarını sürdürebilmek için temel ihtiyaçların başında beslenme gelmektedir. Bir kişinin günlük alması gereken enerjinin \%40-70'ini tahıllar karşılamaktadır. Ekmek ve makarna başta olmak üzere irmik, bisküvi, fırın ve pastacılık ürünleri çok bilinen ve tüketilen tahıl ürünleridir (Yıldırım ve Değer, 2021). Erişte, tahıl ve tahıl ürünleri arasında evde veya endüstriyel olarak yüksek miktarda üretimi yapılan bir gıda ürünüdür. Yapıldığı bölgeye, hammaddeye ve yapılış biçimine göre farklılık içermektedir (Gulia ve ark., 2014). Erişte yüksek miktarda karbonhidrat içerdiği halde pişme sırasında miktarında azalma görülebilmektedir (Öncel, 2017). Tüketicilerin doğal katkılı ve fonksiyonel özellik gösteren sağlıklı ürünlere talebi, gıda alanında yürütülen bilimsel çalışmaların bu yönde ilerlemesine sebep olmuştur (Köten ve Ünsal, 2021). Erişte için de pişme sırasında ortaya çıkan kayıpların azaltılması, ürünün besinsel olarak zenginleştirilmesi ve fonksiyonelliğinin artırılmasına yönelik çalışmalar yapılması gereği ortaya çıkmıştır. Yapılan çalışmalarla farklı içeriğe sahip zengin ürünler üretmek, ürünün besin değerini artırmak hedefenmektedir (Eyidemir, 2006).

Dünyada bulunan en eski bitkiler arasında keçiboynuzu bitkisi (Ceratonia siliqua L.) bulunmaktadır (Medjekal ve ark., 2018). Keçiboynuzunun ilk kullanım yerinin Mısır olduğu ve yaban balı olarak tüketildiği bilinmektedir. Harnup, harup, boynuz isimleri ile de bilinmektedir. Keçiboynuzu ağacının dikiminden sonra meyve vermesi için olgunluğa erme zamanı ortalama 15 yıldır ve bunun sonunda ağaç meyve vermeye başlar. Keçiboynuzu meyvesi olgunlaşmadan önce açık yeşil, olgunluğu süresinde kahverengi renkte olur (Tunalıoğlu ve Özkaya, 2003). Dünya'da keçiboynuzu yaklaşık
200.000 hektarlık bir alanda üretilmektedir. Avrupa'da ise 148.000 ha şeklindedir. Türkiye'de de üretim alanı 13.000 hektardır (Battle ve Tous, 1997). Üretimin \%96'sı Akdeniz kıyılarında yapılmaktadır ve toplam üretim miktarı 14.500ton civarındadır (Durmuş ve Yiğit, 2003). Keçiboynuzu meyvesi yaklaşık 10-15 adet çekirdek içermektedir. Yapılan araştırmalara göre keçiboynuzunun çekirdeklerinin ortalama olarak birbirine yakın gramajlarda olduğu bilindiği için Osmanlı dönemi ve Selçuklu döneminde ağırlık ölçü birimi ve mücevher satışında hassas ölçüme gerek duyulduğu için kullanılmıştır ve günümüzde de mücevher ölçü birimi 'karat' ismi buradan gelmektedir (Şenay, 2009).

Türkiye, keçiboynuzu ağacının kendiliğinden yetiştiği ender ülkeler arasında bulunmaktadır. Ancak, keçiboynuzu meyvesini tüketilebilir bir ürün haline getirebilen yeterli sayıda işletme bulunmamaktadır (Tunalıŏlu ve Özkaya, 2003). Ülkemizde keçiboynuzu meyvesinden çıkarılan çekirdekler işlem görmeden ihraç edilmekte ve keçiboynuzu gamı üretimi ülkemizde yapılamadığı için de ithal edilmektedir. Bu nedenle ülkemiz ekonomik kazanım sağlayamamaktadır (Yılmaz, 2009). Keçiboynuzu gamı gıda sanayiinde katkı maddesi olarak stabilize edici ve hacim verici (kabartıcı), kıvam verici olarak kullanılır. Ürünün bayatlama süresini geciktirmek amacıyla ve yumurta yerine kullanılarak ürüne parçalanmadan kesilebilme özelliği kazandırmak amacıyla kek ve bisküvilerde kullanılmaktadır. Kakao ve kahve ürünü içeren her türlü mamülde ikame olarak değerlendirilmektedir. Keçiboynuzu meyvesi şeker kamışından daha fazla oranda şeker içermektedir. Çekirdeğinden ayrılmış olan keçiboynuzu meyvesinin eteni (yemişlerin yenilen bölümü), ağırlığının \%52'si kadar şeker içerir (Tunalıoğlu ve Özkaya, 2003; Benkovic ve ark., 2019).

Keçiboynuzu unu bitkisel ve doğal bir ürün olma özelliğindedir. Keçiboynuzu meyvesinden 
üretilen unun maliyetinin düşük olması ve ülkemizde yüksek miktarda yetişebilme olanağı ve içerdiği yüksek oranda doğal şeker, protein, diyet lifi, mineral ve vitamin içeriği ile eriştenin zenginleştirilmesi ve fonksiyonelliğinin artırılmasında önemli bir maddedir. Fonksiyonel ürünler elde etmek ve bu ürünlerin değişik gıdalara karıştırılması üzerine birçok çalışma bulunmaktadır (Yağcı ve ark., 2006). Keçiboynuzu çekirdek özü ve protein yapısı ayrıntılı incelendiğinde, esansiyel olmayan amino asitlerin yüksek olduğu görülmüştür. Keçiboynuzu meyvesinin içeriğinde bulunan glutamin ve arjinin amino asitlerinin yüksek olması nedeni ile, keçiboynuzu meyvesinin çekirdek tohumlarından üretilen ürünler, sporcu beslenmesi bakımından ve sporcu performansını yükseltici yönde dikkat çekici olduğu görülmektedir (Yılmaz, 2009). Keçiboynuzu çekirdeği tohumlarının içerisinde, buğday glutenine benzerlik gösteren caroubin isimli protein çeşidini içermektedir (Fidan ve ark., 2019). Beslenme ve fonksiyonel gidalarda kullanılan en önemli gıda bileşenlerinden biri diyet lifidir. Epidemiyolojik çalışmalarda, gastrointestinal hastalıklarda diyet lifi tüketimini arttırmanın hastalıklarda azalma olduğunu göstermiştir Diyet lifinin glisemik indeksi düşük olduğu için kan şekerini yavaş yavaş düşürür. Keçiboynuzu meyvesi içerdiği yüksek lif oranı sayesinde uzun süreli tokluk hissi sağlar ve sindirimi çok yavaştır. Lif içeriği yüksek olduğu için ishal önleyici ve kabızlık şikâyetlerini önleyici besindir. Beslenme öğünlerine eklenen keçiboynuzu diyet lifi, kalp ve damar hastalığı bulunan kişilerde kolestrol seviyesini düşürücü yönde etkisi vardır. Yüksek kolestrol tanısı olan gönüllü hastalar üzerinde yapılan bir araştırmada, 6 hafta süre ile hastaların normal diyetine ek olarak besinlerine eklenen keçiboynuzu lifi araştırma sonucunda, plasebo grubuna göre LDL ve toplam kolesterolde lif verilen hasta grubunda düşüş gözlemlenmiştir. Yapılan çalışmalarda, diyet lifi kullanım oranındaki artış ile sindirim sistemi, çeşitli hastalıklara ve yüksek kolesterole iyileştirici etki gösterdiğini rapor edilmiştir (Papaefstathiou ve ark., 2018). Günümüzde keçiboynuzunda bulunan d-pinitol'ün diyabet ve çeşitli kanser tipleri üzerine olan etkilerinin araştırıldığı çalışmalar mevcuttur. Dünyada beslenme kaynaklı hastalıkların görülme sıklığı artmaktadır. Beslenme alışkanlıklarının işlenmemiş gıdaları tüketme yönünde değişmesi bu tip hastalıkların önlenmesinde önem taşımaktadır (Pazır ve Alper, 2018).

Bu çalışmada, keçiboynuzu unu (KU) ile besin değeri yüksek ve tüketicilerin ilgisini çekebilecek katkılı eriştelerin üretilmesi amaçlanmıştır. Çalışmada kullanılan keçiboynuzu ununun, bitkisel ve doğal bir ürün olmasının yanında maliyetinin düşük olması ve ülkemizde yüksek miktarda yetişebilme olanağı etkinlik ve uygulanabilirlik açısından önemlidir.

\section{Materyal ve Metot}

\section{Materyal}

Erişte üretiminde; Söke marka makarnalık buğday unu kullanılmıştır. Erişte denemelerinde kullanılan keçiboynuzu unu Bağdat Baharatları Gıda San. Tic. Ltd. Şti., Sincan, Ankara'dan temin edilmiştir. Her iki un kullanıma kadar serin ortamda ve kapalı kaplarda muhafaza edilmiştir. Ayrıca üretimde kullanılan tuz ve yumurta Aydın'daki yerel bir marketten satın alınmıştır.

\section{Metot}

\section{Deneme planı}

Denemeler 3 tekerrürlü olarak gerçekleştirilmiştir. Keçiboyunuzu unu erişte formülasyonuna un ağırlığı bazında 4 farklı oranda $(\% 0,5,7.5,10)$ ilave edilmiştir. Formülasyona unun kullanım miktarı üzerinden $\% 0.5$ tuz ve yeterli miktarda su eklenmiştir.

Keçiboynuzu unu ilaveli erişte örneklerinin hazırlanması

Erişte üretiminde kullanılan formülasyon Çizelge $1^{\prime}$ de verilmiştir. Keçiboynuzu unu erişte formülasyonuna un ağırığı bazında 4 farklı oranda $(0,5,7.5$ ve 10) buğday unu ile yer değiştirilerek ilave edilmiştir. Erişte üretiminde Aydın (2009)'ın erişte üretim metodu kullanılmıştır. 
Çizelge 1. Keçiboynuzu unu ilaveli erişte üretim formülasyonu

Table 1 Noodle production formulation with carob flour added

\begin{tabular}{llll}
\hline $\begin{array}{l}\text { Buğday } \\
\text { Unu:Keçiboynuzu } \\
\text { Unu (\%) }\end{array}$ & Su (\%) & Tuz (\%) & $\begin{array}{l}\text { Yumurta } \\
(\%)\end{array}$ \\
$\begin{array}{l}\text { Wheat Flour: } \\
\text { Carob Flour (\%) }\end{array}$ & Water(\%) & Salt(\%) & Egg(\%) \\
\hline 100:0 & 50 & 0.5 & 0.5 \\
$90: 10$ & 50 & 0.5 & 0.5 \\
$92.5: 7.5$ & 50 & 0.5 & 0.5 \\
$95: 5$ & 50 & 0.5 & 0.5 \\
\hline
\end{tabular}

\section{Kimyasal analizler}

Erişte örneklerinin nem (metot 44.01), kül (metot 08.01) ve protein (metot 46.12) içeriklerinin belirlenmesinde AACCI metotları kullanılmıştır (AACCI, 2010). Protein değerlerinin hesaplanmasında azot çevirim faktörü 5.75 alınmıştır.

\section{Pişme Analizleri}

\section{Pişme süresi}

Pişme süresi Köksel ve ark. (2000) tarafından bildirilen metoda göre yapılmıştır. Pişme süresi tayini için, Isıtıcı üzerinde kaynama noktasına gelmiş olan $200 \mathrm{ml}$ saf suya $25 \mathrm{~g}$ erişte katılmış ve kaynayınca kronometre çalıştırılmıştır. Pişme süresinin belirlenmesi için her 1 dakika da bir, erişte şeritleri iki adet lam arasına sıkıştırılmış, eriştelerin ortasındaki beyaz çizgiler yok olana kadar tekrarlanmıştır. Beyaz renkli çizgilerin yok olduğu zamana kadar geçen süre optimum pişme süresi olarak kaydedilmiştir.

\section{Hacim artışı}

Analiz için, çiğ ve pişmiş erişte örnekleri içerisinde belirli miktarda damıtılmış su bulunan dereceli bir silindire konulmuş ve su seviyesindeki artış ölçülmüştür. Hacim artışı denklem 1 kullanılarak hesaplanmıştır (Demir, 2008).

Hacim artışı (\%) $=100 \times$ [ (pişmiş erişte hacmi çiğ erişte hacmi)/çiğ erişte hacmi]

\section{Ağırlık artışı (Su absorbsiyonu)}

Analiz için $25 \mathrm{~g}$ erişte örneği belirlenen süre boyunca pişirilmiştir. Pişirme işleminin ardından süzülen erişteler $5 \mathrm{dk}$. bekletilmiştir. Erişte örneklerinde bulunan su tamamen ayrıldıktan sonra tartım yapılmıştır. Pişirme öncesi ve sonrası erişte tartılmış ve ağırlık artışı denklem 2 kullanılarak hesaplanmıştır (Lai, 2001).

Hacim artışı (\%) = $100 \times$ [ [(pişmiş erişte hacmi çiğ eriște hacmi)/çiğ eriște hacmi]

\section{Pişme kaybı (Suya geçen madde)}

AACC Standart metodu (metot no: 66-50) baz alınarak yapılmıştır. Buna göre $250 \mathrm{ml}$ saf su 500 ml'lik beher içerisinde Soxhelet cihazında kaynatılmış ve içerisine $25 \mathrm{~g}$ erişte örneği ilave edilip $20 \mathrm{dk}$. süreyle pişirme işlemi yapılmıştır. Pişen erişte bunher hunisi yardımıyla 500 ml'lik beherlere süzülmüştür. Süzme işlemi sonrası erişteler $90 \mathrm{ml}$ saf su ile yıkanmıştır. Erişteler bu işlemin ardından bunher hunisinden tekrar süzülmüştür. Toplam yıkama ve pişirme suyunun hacmi 350 ml'ye tamamlanmış ve karıştırma çubuğu yardımı ile iyice karıştırılmıştır. Bu sudan daha önceden sabit tartıma getirilmiş beherlere 50'şer ml alınmıştır. Beherlerin içerisindeki su, su banyosunda kaybolana kadar buharlaştırma işlemi yapılmıştır. Beher içeriği daha sonra $135^{\circ} \mathrm{C}$ 'ye ayarlanmış etüvde sabit ağırlığa gelinceye kadar kurutulmuş ve desikatörde bekletildikten sonra tartılmıştır. Suya geçen madde miktarı denklem 3 yardımıyla hesaplanmıştır (Lai, 2001).

Suya geçen madde miktarı $(\%)=[(\mathrm{Mx} 28) /(100-$ R)] $\times 100$

\section{Toplam organik madde (TOM)}

TOM miktarının belirlenmesi D'Egidio ve ark. (1982)'nın bildirdiği metoda göre yapılmıştır. Yöntem, erişte örneğini pişirdikten sonra bir miktar su ile yıkayıp, örnek yüzeyindeki organik maddelerin suya geçmesini sağlamak ve sonra yıkama suyundaki organik madde miktarını kimyasal yöntem ile belirleme esasına dayanmaktadır. Buna göre; 25 g erişte kaynamakta olan $250 \mathrm{ml}$ distile suda, pişme süresi kadar pişirilmiş, süre sonunda pişen erişte gözenek açıklığı $2 \mathrm{~mm}$ olan süzgeçten süzülmüştür. Sonrasında örnek $5 \mathrm{dk}$. dinlendirilerek içinde $500 \mathrm{ml}$ distile su bulunan behere konulmuş ve $12 \mathrm{dk}$. bekletilmiştir. Bu süre 
içerisinde her 4 dakikada bir karıştırılmıştır. Süre bitiminde yıkama suyundan $5 \mathrm{ml}$ alınarak $600 \mathrm{ml}$ hacmindeki erlene aktarılmış ve $80^{\circ} \mathrm{C}^{\prime}$ de 2 saat evaporasyona bırakılmıştır. Evaporasyon tamamlandıktan sonra örnek üzerine $10 \mathrm{ml}, 1 \mathrm{~N}$ potasyum dikromat ve $20 \mathrm{ml} \% 96$ ' lık sülfürik asit ilave edilerek 1 dakika karıştırılmış ve sonra reaksiyonun gerçekleşmesi için 30 dakika beklenmiştir. Süre sonunda $200 \mathrm{ml}$ distile su ile seyreltme işlemi yapılmış ve sonrasında $1 \mathrm{ml}$ \%0.5'lik difenilamin çözeltisinden ilave edilerek $0.5 \mathrm{~N}$ demir amonyum sülfat çözeltisi ile mor menekşe renkten koyu yeşil renk oluşuncaya kadar titrasyon işlemi yapılmıştır. Sonuç $100 \mathrm{~g}$ örnekten yıkama suyuna geçen nişastanın gram olarak miktarı şeklinde ifade edilmiştir. TOM miktarı denklem 4 yardımıyla hesaplanmıştır.

TOM $=[(B-S) \times(20 / B) \times 3.75 \times 0.9 \times 1.0283] / 2.5$

TOM: Toplam organik madde miktarı

B: Şahit için harcanan $0.5 \mathrm{~N} \mathrm{Fe}(\mathrm{NH} 4) 2$ (SO4)2 miktarı (ml)

$\mathrm{S}$ : Örnek için harcanan $0.5 \mathrm{~N} \mathrm{Fe}(\mathrm{NH} 4)$ 2(SO4)2 miktarı (ml)

20: $10 \mathrm{ml} \mathrm{K}{ }_{2} \mathrm{Cr}_{2} \mathrm{O}_{2}$ çözeltisine karşıllık gelen $\mathrm{Fe}(\mathrm{NH} 4) 2\left(\mathrm{SO}_{4}\right) 2$ miktarı (ml)

3.75: $1 \mathrm{ml} 0.5 \mathrm{~N} \mathrm{Fe}\left(\mathrm{NH}_{4}\right)_{2}\left(\mathrm{SO}_{4}\right)_{2}$ çözeltisine karşlık gelen glukoz miktarı (mg)

2.5: Seyreltme faktörü

\section{Fiziksel Analizler}

\section{Renk analizi}

Keçiboynuzu unu katkılı kuru erişte örneklerinin renginde, katkı dozunun etkisini araştırmak amacıyla, Colorflex RZ Quick Start Guide cihazı kullanılmıştır. Sonuçlar CIE sistemine göre 'L' parlaklık [(0) siyah- (100) beyaz), "a" kırmızılık/yeşillik [(+) kırmızı, (-) yeşil), "b" sarılık mavilik [(+] sarı, (-) mavi)] olarak verilmiştir. Ögütülmüş olan erişte numuneleri kurutma kabına, kabın taban alanında hiçbir boşluk kalmayacak şekilde özenle dökülmüştür. Üç farklı noktadan ölçüm alınarak değerler kaydedilmiştir. Daha sonra ortalamaları alınmıştır (Bakker ve ark., 1986).

\section{Duyusal analiz}

Eriştelerin duyusal analizlerinde $30-40$ yaşları arasındaki 6 eğitimsiz / yarı eğitimli panelist yer almış ve her bir panelistin erişte için verdiği değerlerin ortalaması alınmıştır. Analizlerde koku, lezzet, görünüm, çiğnenebilirilik ve genel beğeni parametreleri kullanılmış ve pişmiş eriştelerde duyusal analiz Köksel ve ark. 1992'ye göre yapılmıştır.

\section{Istatistiksel analizler}

Çalışmada elde edilen tüm veriler istatiksel analize tabi tutulmuştur. İstatistiksel analizler SPSS 22 paket programı ile yapılmıştır. Betimleyici istatistiklerden ortalama ve standart sapma kullanılmıştır. Her bir veri grubunun normal dağılıma uygunluk gösterip göstermediği Kolmogorov-Smirnov testi ile yapılmıştır. Normal dağılım göstermeyen grupların karşılaştılmasında Kruskal Wallis testi kullanılmıştır. Elde edilen veriler varyans analizine tabi tutulmuş, farklılıkları istatistiki olarak önemli bulunan ana varyasyon kaynaklarının ortalamaları ise, Duncan çoklu karşılaştırma testi ile $(p<0.05)$ kıyaslanmıştır.

\section{Araştırma Bulguları ve Tartışma}

\section{Kimyasal özellikler}

Gıdalarda raf ömrü nem miktarından etkilenmekte; kimyasal ve mikrobiyolojik etkileri olabilmektedir (Köten ve ark., 2014). Çizelge 2'de verilen sonuçlara göre; en yüksek nem içeriği kontrol eriştesinde tespit edilmiştir. \%9.40 ortalama nem miktarıdır. 
Çizelge 2: Erişte örneklerinde nem, kül ve pretein miktarı sonuçları (\%)

Table 2. Moisture, ash and protein content results in noodle samples (\%)

\begin{tabular}{|c|c|c|c|}
\hline $\begin{array}{l}\text { Erişte Örnekleri } \\
\text { Noodle Samples }\end{array}$ & $\begin{array}{l}\text { Nem analizi (\%) } \\
\text { Mositure analysis(\%) }\end{array}$ & $\begin{array}{l}\text { Kül analizi(\%) } \\
\text { Ash analysis(\%) }\end{array}$ & $\begin{array}{l}\text { Protein analizi (\%) } \\
\text { Protein analysis (\%) }\end{array}$ \\
\hline $\begin{array}{l}\text { Kontrol } \\
\text { Control }\end{array}$ & $9.49 \pm 0.04^{a}$ & $1.24 \pm 1.05^{d}$ & $13.50 \pm 0.07^{a b}$ \\
\hline $\begin{array}{l}\% 5 \mathrm{KU} \text { eklenmiş erişte } \\
\text { Noodles with } 5 \% \text { CF added }\end{array}$ & $9.34 \pm 0.04^{a}$ & $1.41 \pm 0.02^{c}$ & $13.62 \pm 0.11^{\mathrm{ab}}$ \\
\hline $\begin{array}{l}\% 7.5 \mathrm{KU} \text { eklenmiş erişte } \\
\text { Noodles with } 7.5 \% \text { CF added }\end{array}$ & $9.71 \pm 0.04^{a}$ & $1.65 \pm 0.13^{b}$ & $13.92 \pm 0.03^{b c}$ \\
\hline $\begin{array}{l}\% 10 \mathrm{KU} \text { eklenmiş erişte } \\
\text { Noodles with } 10 \% \text { CF added }\end{array}$ & $9.09 \pm 0.62^{b}$ & $1.75 \pm 0.14^{\mathrm{a}}$ & $14.16 \pm 0.19^{c d}$ \\
\hline $\begin{array}{l}\text {-Parametreler kuru madde ü } \\
\text {-The parameters are given in } \\
\text {-Aynı satırda farklı harf taşı } \\
>0.05) \text {. } \\
\text {-Averages with different lett } \\
\text { are not different }(p>0.05) \text {. }\end{array}$ & $\begin{array}{l}\text { inden verilmiştir. Protei } \\
y \text { matter. Protein calculc } \\
\text { ortalamalar birbirinde } \\
\text { on the same row are } d\end{array}$ & $\begin{array}{l}\text { ü ile hesaplanmıştır } \\
\text { actor of } 5.75 \\
0.05) \text {, aynı harf taşıya } \\
\text { each other }(P<0.05) \text {, }\end{array}$ & 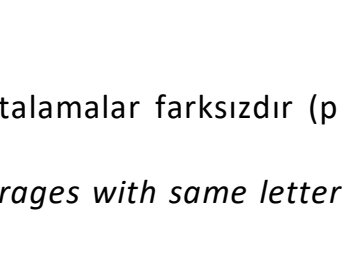 \\
\hline
\end{tabular}

Çizelge 2'ye göre nem değerleri, kontrol (\%0) örneğinde miktarı \%9.49, \%5 KU ilaveli örnekte \%9.34, \%7.5 KU ilaveli örnekte \%9.71, \%10 KU ilaveli örnekte \%9.09 olarak kaydedilmiştir. Uygulanan varyans analizi sonucunda, grup ortalamaları arasında fark anlamlıdır $(p<0.05$, $\mathrm{p}=0.015)$. $\% 0$ ve $\% 5^{\prime}$ lik numunelerde istatistiksel olarak açıdan anlamlı farklıık tespit edilmiştir. En az nem değeri \%5'lik KU numunede görülmüştür. Bir çalışmada erişteye muz unu ilave edilmiş ve nem oranı \%10.07-8.67 olarak bulmuştur. Muz unu katkısı nem miktarını azaltmıştır (Ritthiruangdej, 2011). Kayısı çekirdeği unu ile yapılan başka bir çalışmada örneklerin \% nem içerikleri kontrol örneğinden anlamlı olarak düşük kaydedilmiştir (Eyidemir, 2006). Başka çalışmada ise kinoa unu erişteye katılmış, hem un hem su miktarı arttırılınca son üründe de nem içeriği kontrol örneğinden yüksek bulunmuştur (Ene, 2017). Eriş̧e yapımında keten tohumu kullanılan bir çalışmada ise nem oranlarında azalma görülmüştür (Yüksel ve ark, 2018).

Farklı dozlarda keçiboynuzu unu ilave edilmiş erişte kontrol (\%0) için kül \%1.24, \%5 keçiboynuzu unu ilaveli erişte örneği için \%1.41, \%7.5 keçiboynuzu unu ilaveli $\% 1.65$ ve $\% 10$ keçiboynuzu unu ilaveli örnek \%1.75 olarak kaydedilmiştir ve aralarında anlamlı bir farklılık olduğu tespit edilmiştir $(p<0.05, \quad p=0.015)$. Eriştelerin kül içerikleri keçiboynuzu unu ilavesine bağlı olarak artmıştır. En düşük değer kontrol örneğinde $\% 1.24$, en yüksek $\% 1.75$ ile $\% 10$ keçiboynuzu unu ilavesiyle üretilen eriştelerde bulunmuştur. $\% 0$ ve $\% 10$ keçiboynuzu unu ilaveli erişteler arasında anlamlı bir fark gözlemlenmiştir $(p<0.05, p=0.015)$. Keçiboynuzu unu ilavesi artıkça kül miktarının artmasında keçiboynuzu ununun zengin mineral içeriğinin etkisi olduğundan kaynaklandığı düşünülmektedir. Bu durum, keçiboynuzu ununun sahip olduğu yüksek kül miktarından kaynaklandığı söylenebilir. Çalışmamızda üretilen keçiboynuzu unu katkılı eriştenin yüksek kül miktarına sahip olması aynı zamanda yüksek mineral madde içermesi ile ilgili olması yönünden de besleyici bir gıda maddesi olarak günlük beslenmemizde değerlendirilebilir.

Chillo ve ark. (2008), yaptıkları çalışmada amarant üzerine kinoa ilaveli makarna örneklerinin kül miktarıın (\%2.24), kontrol eriştesine (\%0.81) kıyasla daha yüksek olduğunu ve bu değişimin istatistiksel olarak önemli bulunduğunu tespit etmişlerdir. Rosa ve ark. (2015), karabuğday eriştelerine amarant ve pirinç ununun etkilerini araştırdıkları çalışmalarında tüm ikame oranlarının kontrol örneğinden (\%100 karabuğday) daha yüksek kül içeriğine sahip olduğunu ve en yüksek kül içeriğinin \%15 amarant + \%15 piriç unu ikameli erişte örneklerinde olduğunu tespit etmişlerdir. Man ve arkadaşlarının 2016 yılında yaptıkları çalışmada kül miktarının \%25 karabuğday unu ilavesiyle $\% 1,43$ 'e yükseldiğini tespit etmişler ve buğday 
ununa karabuğday unu ikame oranı arttıkça eriştelerin kül miktarının da arttığını bildirmişlerdir (Man ve ark., 2016). Aydın'ın (2009) yaptığı çalışmada yulaf unu ilavesinin kül miktarını arttırdığını tespit etmiştir, yaptığımız çalışma ile sonuçlar benzerlik göstermektedir.

Farklı dozlarda keçiboynuzu unu ilave edilmiş erişte örnekleri için protein değerleri (\%) şöyle bulunmuştur: Kontrol (\%0) örneği için protein miktarı \%13.5, \%5 KU ilaveli erişte örneği için \% $13.62, \% 7.5 \mathrm{KU}$ ilaveli erişte örneği için \%13.92 ve \%10 keçiboynuzu unu ilaveli erişte örneği için protein miktarı \%14.16 olarak kaydedilmiştir $(p<0.05, p=0.0015)$. Kontrol $(\% 0)$ eriştesi ve \%10 keçiboynuzu unu ilaveli erişte arasında anlamlı bir fark tespit edilmiştir. Fakat kontrol eriştesinin, keçiboynuzu ilaveli örneklere göre düşük protein değerinde olduğu gözlemlenmiştir. Keçiboynuzu unu ilave oranı arttıkça protein miktarının arttığı gözlemlenmiştir ( $p<0.05, p=0.015)$.

Yapılan bir çalışmada hindistan ceviz unu katkılı eriştede protein değerleri kontrol örneğinde $\% 11.2$ olarak belirlenirken, $\% 10, \% 20, \% 30$ ilaveli örneklerde sırasıyla \%12, \%14 ve \%19 olarak tespit edilmiştir (Gunathılake ve Abeyrathne, 2008). Ginting ve Yulifanti (2015), yaptıkları çalışmada turuncu etli patates unu katkılı eriştelerin protein miktarını, kontrol örneğine göre daha düşük bulmuşlardır. Yapılan çalışmada amaçlanan, protein kalitesi düşük olan ekmek, makarna, erişte gibi unlu mamulleri göz önünde bulundurarak; protein kalitesi iyileştirilmiş, günlük diyette yer verilebilecek, fonksiyonel özellikte bir ürün olarak keçiboynuzu unu ilaveli erişe üretimini araştırmaktır. Elde edilen veriler kapsamında bu ürünün kabul edilebilir olduğu da görülmektedir.

\section{Fiziksel özellikler}

Erişte örneklerinin $L^{*}, a^{*}, b^{*}$ renk değerleri ve gruplar arası tek yönlü varyans analizi (ANOVA) sonuçları Çizelge 3 'de gösterilmektedir.

Çizelge 3. Erişte örneklerinin renk analizi sonuçları

Table 3. Color analysis results of noodle samples

\begin{tabular}{|c|c|c|c|}
\hline $\begin{array}{l}\text { Erişte Örnekleri } \\
\text { Noodle Samples }\end{array}$ & $\begin{array}{l}\text { Renk analizi } \\
\text { Color analysis } \\
\text { L* }^{*}\end{array}$ & $a^{*}$ & $b^{*}$ \\
\hline $\begin{array}{l}\text { Kontrol } \\
\text { Control }\end{array}$ & $68.39 \pm 0.20$ & $5.72 \pm 0.02$ & $20.96 \pm 0.07$ \\
\hline $\begin{array}{l}\% 5 \mathrm{KU} \text { eklenmiş erişte } \\
\text { Noodles with } 5 \% \text { CF added }\end{array}$ & $37.87 \pm 1.19$ & $4.87 \pm 0.13$ & $10.22 \pm 0.25$ \\
\hline $\begin{array}{l}\text { \%7.5 KU eklenmiş erişte } \\
\text { Noodles with } 7.5 \% \text { CF added }\end{array}$ & $35.11 \pm 3.58$ & $5.12 \pm 0.06$ & $10.25 \pm 0.11$ \\
\hline $\begin{array}{l}\% 10 \text { KU eklenmiş erişte } \\
\text { Noodles with } 10 \% \text { CF added }\end{array}$ & $32.49 \pm 1.47$ & $4.73 \pm 0.07$ & $08.53 \pm 0.14$ \\
\hline $\begin{array}{l}\text { - L: Parlaklık; a (+): Kırmızııı; } \\
\text { - istatiksel açıdan önemsizdir } \\
\text { L: Brightness; a (+): Redness; } \\
\text { - statistically insignificant (p< }\end{array}$ & iess & & \\
\hline
\end{tabular}




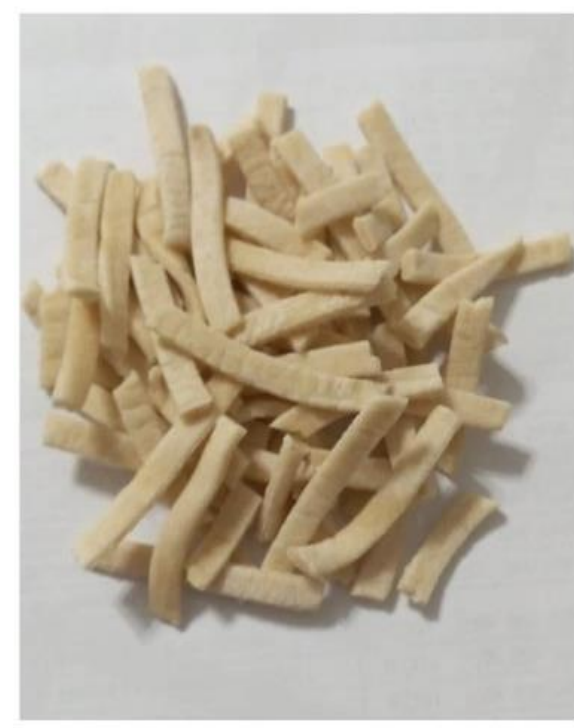

Kontrol (100:0) örneği

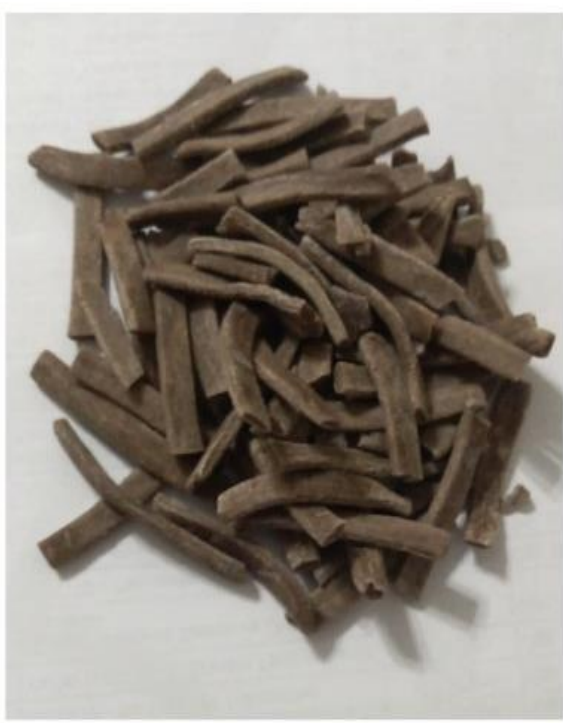

\%7,5 KU Katkılı Erişte

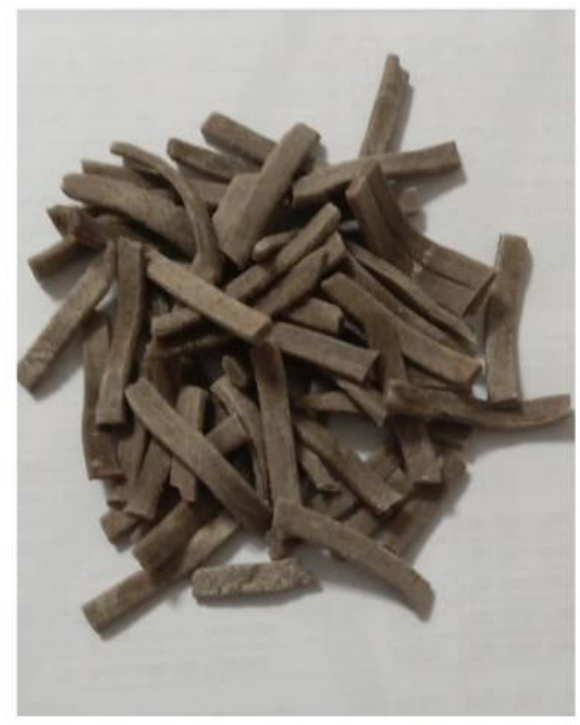

$\% 5$ KU Katkılı Erişte

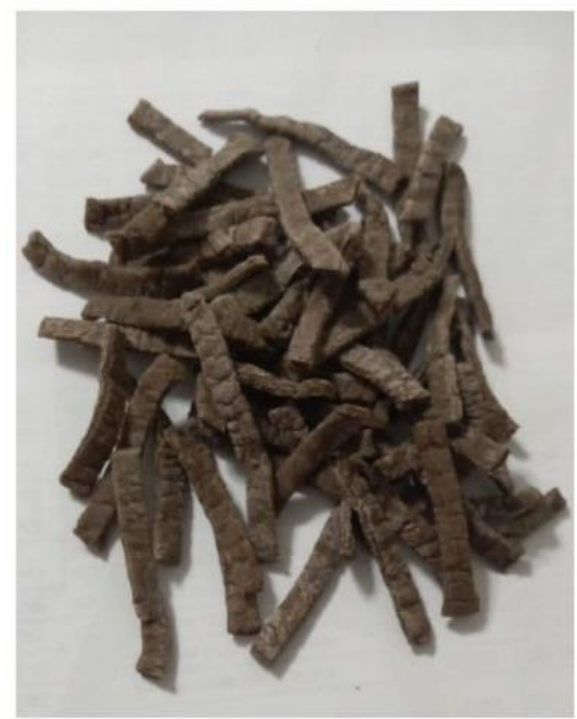

\%10 KU Katkılı Erişte
Şekil 1. Renk analizinde kullanılan erişte örnekleri Figure 1. Noodle samples used in color analysis
Renk analizi sonucuna göre $L$ değerleri, kontrol (\%0) örneği için 68.39, \%5 keçiboynuzu unu ilaveli erişte örneği için, \%37.87, \%7.5 keçiboynuzu unu ilaveli örnek için \%35.11 ve \%10 keçiboynuzu unu ilaveli örnek için, \%32.49 olarak kaydedilmiştir. a değerleri kontrol (\%0) örneği için, $5.72 \% 5$ keçiboynuzu unu ilaveli erişte örneği için \%4.87, \%7.5 keçiboynuzu unu ilaveli erişte örneği için 35.11, \%10 keçiboynuzu unu ilaveli erişte örneği için \%4.73 olarak kaydedilmiştir. b değerleri kontrol (\%0) örneği için 20.96, \%5 keçiboynuzu unu ilaveli erişte örneği için \%10.22, \%7.5 keçiboynuzu unu ilaveli erişte örneği için \%10.25,
\%10 keçiboynuzu unu ilaveli erişte örneği için \%8.53 olarak kaydedilmiştir. İstatistiki analiz ile grup ortalamaları arasında anlamlı bir farklılık olduğu tespit edilmiştir $(p \leq 0.05, p=0,05)$.

\section{Pişme özellikleri}

Erişte ve makarnalarda pişme kalitesinin belirlenmesinde ağırlık artışı, hacim artışı ve suya geçen madde miktarı (SGM) gibi analizler bu ürünlerin kalite yönünden değerlendirilmesinde önemli kriterlerdendir (Köten ve ark., 2013). Üretimi yapılan erişte örneklerinin pişme testi sonuçları Çizelge 4'de verilmiştir. 
Çizelge 4. Erişte örneklerine uygulanan pişme analizi sonuçları

Table 4. Cooking analysis results applied to noodle samples

\begin{tabular}{|c|c|c|c|}
\hline $\begin{array}{l}\text { Erişte örnekleri } \\
\text { Noodle samples }\end{array}$ & $\begin{array}{l}\text { Hacim artışı (\%) } \\
\text { Inrease of volume }\end{array}$ & $\begin{array}{c}\text { Ağırlık artışı(\%) } \\
\text { Increase of weight }\end{array}$ & $\begin{array}{c}\text { SGM (\%) } \\
\text { Quantities of substance in water }\end{array}$ \\
\hline Kontrol & $245.00 \pm 12.40^{a}$ & $286.47 \pm 16.07^{a}$ & $2.30 \pm 0.38^{d}$ \\
\hline Control & & & \\
\hline $\begin{array}{l}\% 5 \mathrm{KU} \text { eklenmiş erişte } \\
\text { Noodles with } 5 \% \text { CF added }\end{array}$ & $298.33 \pm 18.97^{a}$ & $262.70 \pm 18.97^{a b}$ & $1.70 \pm 0.43^{c}$ \\
\hline $\begin{array}{l}\text { \% } 7.5 \text { KU eklenmiş erişte } \\
\text { Noodles with } 7.5 \% \text { CF added }\end{array}$ & $334.12 \pm 29.15^{\mathrm{ab}}$ & $281.81 \pm 29.15^{b c}$ & $1.36 \pm 0.14^{\mathrm{a}}$ \\
\hline $\begin{array}{l}\% 10 \mathrm{KU} \text { eklenmiş erişte } \\
\text { Noodles with } 10 \% \text { CF added }\end{array}$ & $335.79 \pm 27.80^{\mathrm{ab}}$ & $273.56 \pm 27.80^{\mathrm{bd}}$ & $1.17 \pm 0.15^{\mathrm{ab}}$ \\
\hline \multicolumn{4}{|c|}{$\begin{array}{l}\text {-SGM: Suya geçen madde miktarı } \\
\text { - SGM: Quantities of substance in Water } \\
\text {-Çizelgede, aynı satırda farklı harfle gösterilen değerler arasındaki farklar } 0.05 \text { güven sınırına göre önemlidir. } \\
\text { - In the table, differences between values shown with different letters in the same line are significant compared to } \\
\text { the } 0.05 \text { confidence level }\end{array}$} \\
\hline
\end{tabular}

Eriştelerde ağırlık artışı 262.7-286.47, hacim artışı 245-335.79 ve suya geçen madde miktarı ise 1.17-2.30 değerleri arasında değişkenlik göstermektedir. Pişme işlemi sırasında eriştelerin kütle ve hacim artışının yüksek olması beklenmektedir. Zayıf su baglama kapasitesi kütle artışının az olmasına ve ve eriştenin sert olmasına sebep olabilmektedir (Wandee ve ark., 2014). Erişte daha az su çekerse de hacim artışı az ve sert bir erişte oluşmasına neden olabilmektedir (Bhattacharya ve ark., 1999).

Ağılık artışı erişte örneklerinde, Çizelge 4 'den anlaşılacağı üzere \%262.7- 286.47 değişmiştir. Ağırlık artışı en fazla kontrol (\%0) eriştesinde görülmüştür. Ağırlık artışı keçiboynuzu unu eklenmesi ile \%5KU ve \%10KU ilaveli erişte örneklerinde azalırken, \%7.5 KU ilaveli erişte örneğinde artış göstermiştir. Bu farklı değişim oranına yoğurma işlemi aşamasında farklılık, homojen şekilde keçiboynuzu ununun buğday ununa karışamamış olmasının neden olduğu ve keçiboynuzu unu miktarı arttıkça moleküller arası protein ve su bağlama özelliklerinin değişmesi gibi nedenlerden kaynaklanmış olabileceği tahmin edilmektedir. Kruskall walls testi sonuçlarına göre KU ilavesiyle eriştelerde ağırık artışı kontrole göre önemli düzeyde ( $p<0.05, p=0.016)$ azalma göstermektedir. KU miktarı arttıkça gruplarda ağırlık artışında azalma görülmektedir. Buğday ununda yapısında bulunan gluten proteini yüksek su tutma kapasitesine sahip olduğundan keçiboynuzu ununun aşamalı olarak buğday unuyla yer değiştirmesinden ötürü gluten içeriği seyrelmekte ve erişte hamurunun yapısı gluten bakımından zayıflamaktadır.

Yapılan diğer benzer çalışmalar incelendiğinde bulunan sonuçlar şöyledir; Kayısı çekirdeği ununun eklendiği erişte örneklerinde \% ağırlık artışı kayısı çekirdeği unu artıkça azalmıtır. \% ağırlık artışındaki azalmaya neden, kayısı çekirdeği unu arttıkça pişme süresinin kısalması olarak görülmüştür. Yani pişme süresi artması ile eriştelerin su absorplaması artmakta, dolayısıyla ağırlıkları artış göstermektedir (Eyidemir, 2006). Başka bir çalışmada erişte formülasyonuna yulaf unu ilavesi de \% ağırlık artışını yükseltmiştir (Aydın, 2009). Bu sonuçlara paralel olarak kinoa unu eklenmiş erişte örneklerinde de kinoa unu miktarı arttıkça, \% ağırlık artışının yani su absorpsiyonunun arttığı gözlenmiştir. Bunun sebebi, erişte formülasyonunda buğday unu dışındaki bileşenlerin, gluten proteinlerinin ağ yapısında kopukluklar yaratması olduğu belirtilmiştir (Eyidemir, 2006).

Erişte örneklerinde Çizelge 4'dan de anlaşılacağı gibi ortalama hacim artışı $303.31 \pm 21.92$ olarak saptanmıştır. En yüksek hacim artışı 335.79 ile \%10 KU ilaveli örneğinde saptanırken, en düşük hacim artışı 245 ile kontrol (\%0 ilaveli erişte) örneğinde görülmüştür. Kruskal walls testi sonuçları incelendiğinde keçiboynuzu unu ilaveli hacim artışında belirgin $(p<0.05$, $p=0,001$ ) bir artış gözlemlenmiştir. Çalışmada analiz sonuçlarına göre üretilen eriştelerin iyi 
kaliteli olduğu da gözlemlenmiştir.

Erişte örneklerinde pişme kaybı yapışkan bir yapıya sahip olmasına neden olur. Üretilen eriştelerde suya geçen madde miktarı ortalama 1.17-2.30 olarak bulunmuştur. Konrol grubunda SGM oranı 2.30 iken \%10 KU ilaveli erişte örneğinde 1.17 belirlenmiştir ( $p<0.05, p=0,015)$. Kontrol ile \%10 Ku ilaveli örnekte anlamlı farklılık tespit edilmiştir. Keçiboynuzu unu oranı arttıkça erişte örneklerinde SGM oranı azalmaktadır. SGM $\% 6^{\prime}$ dan az ise çok iyi kalitede erişte, $\% 8^{\prime}$ den fazla olması erişte kalitesinin çok düşük olduğunu gösterir (Köksel ve ark., 2000). Çalışmamızda suya geçen madde miktarı azalma göstermiştir. Verilen değer aralıklarına göre ise üretilen keçiboynuzu unu katkılı eriştelerin yüksek kalitede olduğu belirlenmiştir.

Çizelge 5: Erişte örneklerinin optimum pişme süreleri (saniye)

Table 5: Optimum cooking times of noodle samples (seconds)

\begin{tabular}{lc}
\hline $\begin{array}{l}\text { Erişte örnekleri } \\
\text { Noodle samples }\end{array}$ & $\begin{array}{c}\text { Pişme süresi (Saniye) } \\
\text { Cooking times(Second) }\end{array}$ \\
\hline $\begin{array}{l}\text { Kontrol } \\
\text { Control }\end{array}$ & $513 \pm 1.43$ \\
$\% 5$ KU eklenmiş erişte & $547 \pm 1.44$ \\
Noodles with 5\% CF added & \\
$\% 7.5$ KU eklenmiş erişte & $600 \pm 0.00$ \\
Noodles with 7.5\% CF added & \\
$\% 10$ KU eklenmiş erişte & $633 \pm 1.43$ \\
Noodles with 10\% CF added &
\end{tabular}

Erişte ve makarna gibi ürünlerin pişme özellikleri hem besinsel kalite hem de tüketici kabul edilebilirliği açısından önem taşımaktadır. Optimum pişme süresinin belirlenmesi ürünün pişme özelliklerini de doğrudan etkilemektedir. Bu çalışmada geleneksel yöntemler ile üretilen ev erişte formülasyonuna, buğday unu ağırlığı üzerinden; $\% 0$ (Kontrol), $\% 5, \% 7.5$ ve $\% 10$ miktarlarında keçiboynuzu unu ilave edilmiştir. Kontrol eriştesinin 8 dakika 33 saniye, \%5 KU ilaveli erişte örneği 9 dakika 7 saniye, \%7.5 KU ilaveli erişte örneği 10 dakika, \%10 KU ilaveli erişte örneği ise 10 dakika 33 saniyede pişmiştir. Erişte örneklerinin optimum pişme süreleri belirlendikten sonra bu verilere kruskal walls analizi uygulanmıştır $(p<0.05, p=0,024)$. Sonuç olarak, erişte örneklerine buğday unu ağırlığı üzerinden \%10 miktarına kadar keçiboynuzu unu ilave edilmesinin pişme süresi üzerinde istatistiksel olarak önemli bir artış ya da azalış yaratmadığı görülmüştür. KU miktarı arttıkça pişme süresinin uzadığı tespit edilmiştir.

Toplam organik madde (TOM) miktarı, pişmiş makarnaların üst tabakasından bulunan organik bileşenlerin durulama suyu ile yıkanarak belirlenmesi kuralına dayanır ( $D^{\prime}$ Egidio ve Nardi, 1996). Erişte örneklerinin keçiboynuzu unu miktarları tüm analizlerde esas alındığında \%2.5 (kontrol) örneğinde \%1.85, (\%5 KU) ilaveli örnekte \%1.5 ile (\%7.5 KU) ilaveli örnekte \%1.17 (\%10 KU) ilaveli örnekte görülmüştür. Keçiboynuzu unu oranı arttıkça toplam organik madde miktarınında düştüğü gözlemlenmiştir. \%0 kontrol- \%10 KU ilaveli örnek arasına anlamlı bir farklılık tespit edilmişitir $(p<0.05, p=0.015)$. Bu bulgular ile glutensiz unların makarna üretim aşamasına ilave edilmesi gluten yapısının zayıflamasına neden olmuştur denilebilir. Sonuç olarak tüm yapının olumsuz etkilendiği belirlenmiştir.

\section{Duyusal özellikler}

Farklı oranlarda keçiboynuzu unu ilave edilerek yapılan erişte örneklerine duyusal analliz testi uygulanmıştır. Duyusal analizde erişte numunelerinde renk, koku, lezzet, görünüm, çiğnenebilirlik ve genel beğeni parametreleri bakımından 5 puanlı bir skala üzerinden değerlendirilmiştir. Duyusal analiz sonucu tüm parametrelerde Kruskall Waillis analizi uygulanmıştır. Analiz sonucu elde edilen veriler Çizelge 6 ile gösterilmiştir. Buna göre elde edilen sonuçlar şu şekilde kaydedilmiştir.

Renk parametresine ait duyusal analiz verileri kontrol $(\% 0)$ erişte örneği için $0.3 \pm 4.4$, \%5 keçiboynuzu unu katkılı erişte örneği $4 \pm 0.3$, \%7.5 keçiboynuzu unu katkılı erişte örneği için $1.3 \pm$ 0.8, \%10 keçiboynuzu unu katkılı erişte örneği için $4.3 \pm 0.5$ olarak belirlenmiştir. Koku parametresine ait duyusal analiz verileri kontrol (\%0) erişte örneği için $3.70 \pm 0.66$, \%5 keçiboynuzu unu katkılı erişte örneği $3.83 \pm 0.79$, 
\%7.5 keçiboynuzu unu katkılı erişte örneği için 4.5 $\pm 0.87, \% 10$ keçiboynuzu unu katkılı erişte örneği için $4.66 \pm 0.54$ olarak belirlenmiştir. Lezzet parametresine ait duyusal analiz verileri kontrol (\%0) erişte örneği için $3.16 \pm 1.22$, \%5 keçiboynuzu unu katkılı erişte örneği için $3.11 \pm$ 0.79, \%7.5 keçiboynuzu unu katkılı erişte örneği için $4.16 \pm 0.42$, \%10 keçiboynuzu unu katkılı erişte örneği için $4.83 \pm 0.42$ olarak belirlenmiştir. Görünüm parametresine ait duyusal analiz verileri kontrol $(\% 0)$ erişte örneği için $3.66 \pm 1.22$, \%5 keçiboynuzu unu katkılı erişte örneği için $3.33 \pm$ 0.85, \%7.5 keçiboynuzu unu katkılı erişte örneği için $4.33 \pm 0.54, \% 10$ keçiboynuzu unu katkılı erişte örneği için $4.66 \pm 0.54$ olarak belirlenmiştir. Çiğnenebilirlik parametresine ait duyusal analiz verileri kontrol (\%0) erişte örneği için $3.16 \pm 0.79$, $\% 5$ keçiboynuzu unu katkılı erişte örneği için $4 \pm$ 0.93, \%7.5 keçiboynuzu unu katkılı erişte örneği için $4 \pm 0.66$, \%10 keçiboynuzu unu katkılı erişte örneği için $4.33 \pm 0.85$ olarak belirlenmiştir.

Çizelge 6: Erişte örneklerine uygulanan duyusal analiz sonuçları ve Kruskal Wallis analizi sonuçları Table 6: Sensory analysis results and Kruskal Wallis analysis results applied to noodle samples

\begin{tabular}{|c|c|c|c|c|c|c|}
\hline $\begin{array}{l}\text { Erişte Örnekleri } \\
\text { Noodle Samples }\end{array}$ & $\begin{array}{l}\text { Renk } \\
\text { Color }\end{array}$ & $\begin{array}{l}\text { Koku } \\
\text { Smell }\end{array}$ & $\begin{array}{l}\text { Lezzet } \\
\text { Flavor }\end{array}$ & $\begin{array}{l}\text { Görünüm } \\
\text { Texture }\end{array}$ & $\begin{array}{l}\text { Çiğnenebilirlik } \\
\text { Chewiness }\end{array}$ & $\begin{array}{l}\text { Genel beğeni } \\
\text { Overall } \\
\text { acceptability }\end{array}$ \\
\hline $\begin{array}{l}\text { Kontrol } \\
\text { Control }\end{array}$ & $0.3 \pm 4.4^{a}$ & $3.70 \pm 0.66^{a b}$ & $3.16 \pm 1.22^{b c}$ & $3.66 \pm 1.22^{b c}$ & $3.16 \pm 0.79^{d}$ & $3.33 \pm 1.20^{\mathrm{a}}$ \\
\hline $\begin{array}{l}\% 5 \text { keçiboynuzu } \\
\text { unlu erişte } \\
\text { Noodles with 5\% CF } \\
\text { added }\end{array}$ & $0.3 \pm 4.0^{\mathrm{ab}}$ & $3.83 \pm 0.79^{b}$ & $3.11 \pm 0.79^{a}$ & $3.33 \pm 0.85^{b}$ & $4.00 \pm 0.93^{c}$ & $3.66 \pm 0.90^{a b}$ \\
\hline $\begin{array}{l}\text { \% } 7.5 \text { keçiboynuzu } \\
\text { unlu erişte } \\
\text { Noodles with } 7.5 \% \\
\text { CF added }\end{array}$ & $1.3 \pm 0.8^{b c}$ & $4.5 \pm 0.87^{c}$ & $4.16 \pm 0.42^{b}$ & $4.33 \pm 0.54^{a}$ & $4.00 \pm 0.66^{b}$ & $4.33 \pm 0.60^{\mathrm{ab}}$ \\
\hline $\begin{array}{l}\% 10 \text { keçiboynuzu } \\
\text { unlu erişte } \\
\text { Noodles with } 10 \% \\
\text { CF added }\end{array}$ & $4.3 \pm 0.5^{b c}$ & $4.66 \pm 0.54^{c d}$ & $4.83 \pm 0.42^{b c}$ & $4.66 \pm 0.54^{a}$ & $4.33 \pm 0.85^{\mathrm{a}}$ & $4.88 \pm 0.90^{b}$ \\
\hline $\begin{array}{l}\text { Ort (std) } \\
\text { Avr (std) }\end{array}$ & $1.55 \pm 2.4$ & $4.17 \pm 0.71$ & $3.8 \pm 0.71$ & $3.9 \pm 0.78$ & $3.87 \pm 0.80$ & $4.05 \pm 0.90$ \\
\hline $\begin{array}{l}\text { Min- Maks } \\
\text { Min-Max }\end{array}$ & $0.3-4.3$ & $3.70-4.66$ & $3.11-4.83$ & $3.33-4.66$ & $3.16-4.33$ & $3.33-4.88$ \\
\hline
\end{tabular}

Çizelgede, aynı satırda farklı harfle gösterilen değerler arasındaki farklar 0.05 güven sınırına göre önemlidir. In the table, differences between values shown with different letters in the same line are significant compared to the 0.05 confidence level

Genel beğeni parametresine ait duyusal analiz verileri kontrol (\%0) erişte örneği için $3.33 \pm 1.2$, $\% 5$ keçiboynuzu unu katkılı erişte örneği için 3.66 \pm 0.9 , \%7.5 keçiboynuzu unu katkılı erişte örneği için $4.33 \pm 0.6$, \%10 keçiboynuzu unu katkılı erişte örneği için $4.88 \pm 0.9$ olarak belirlenmiştir.

Eriştelerin renk değerleri 0.3-4.3 arasında değişiklik göstermiştir. Renk değerlerine bakıldığında \%10 KU ilaveli örnek en yüksek puanı almıştır. KU oranı azaldıkça renk skalası için verilen değerlerde düşüş gözlemlenmiştir. Kruskal walls testi sonuçlarına göre gruplarda renk puanı açısından anlamlı bir farklılık tespit edilmemiştir ( $p>0.05, \quad p=0.074)$. Tüm KU ilaveli erişte örneklerinin kabul edilebilir duyusal özellik puanlarına sahip olduğu, ancak \%0 kontrol örneğine kıyasla koyu renge sahip olduğu tespit edilmiştir.

\section{Sonuç}

$\mathrm{Bu}$ araştırma sonucunda erişte örneklerine KU ilave edilerek yeni ürün elde edilmesinin ve insan sağlığı açısından da besleyici özelliklerinin iyileştirilmesinin mümkün olduğu belirlenmiştir. Keçibounuzu ununun doğal bir katkı maddesi olarak belli oranlarda kullanılması ile kabul edilebilir nitelikte erişte 
yapılabilmesi ve böylelikle keçiboynuzu ununun gıda sanayine kazandırımasıyla, lif yönünden zengin gıdalar, mevcut teknolojiyle ve düşük maliyetlerle üretilebilecektir. Sektöre yeni ve daha sağııklı ürünler kazandırılmış olacaktır. Keçiboynuzu meyvesinden üretilen unun erişteye ilave edilmesiyle, bu meyvenin yaygın olarak kullanması sağlanacaktır. Keçiboynuzu meyvesi katkılı gıda maddeleri sağlık üzerine olumlu etkileri nedeniyle daha çok tercih edilecektir. Aynı zamanda keçiboynuzu yetiştiriciliği bu sayede önem kazanacak ve bu da tarım sektöründe keçiboynuzu meyvesinin pazar payını arttıracaktır.

\section{Ekler}

Bu çalışma, Burçin Başarık ŞEN'in Yüksek Lisans Tezinden yararlanarak hazırlanmıştır. Bu çalışmanın özeti, 13-15 Kasım 2020 tarihlerinde Ankara'da düzenlenen 5. Uluslararası Tarım, Hayvancılık ve Kırsal Kalkınma Kongresi'nin bildiri kitabında yayınlanmıştır.

\section{Çıkar Çatışması Beyanı: Makale yazarları} aralarında herhangi bir çıkar çatışması olmadığını beyan ederler.

\section{Yazar Katkısı: illkay YILMAZ makalenin} kavramsallaştırma, metodoloji, biçimsel analiz, yazma-orijinal taslak, yazma-inceleme, düzenleme ve görselleştirmesine katkı sunmuştur. Burçin Başarık ŞEN makaleye metodoloji, biçimsel analiz, istatistiksel analiz ve görselleştirme olarak katkı sağlamıştır. Yazarlar makalenin son halini okumuş ve onaylamıştır.

\section{Kaynaklar}

AACCI. (2010). Approved Methods of the American Association of Cereal Chemists. Approved Methods of Analyses 11th Edition, The Association: St. Paul, MN.

Anonim, (2002). Tarım ve Köyişleri Bakanlığı ile Sağlık Bakanlığı, Resmi Gazete: 5 Mart 2002 - 24686, Türk Gıda Kodeksi, Makarna Tebliği, Tebliğ No: 2002/ 20, Ankara, 2002

Aydın, E. (2009). Yulaf Katkısının Eriştenin Kalite Kriterlerine Etkisi. (Yayınlanmış yüksek lisans tezi), Uludağ Üniversitesi, Fen Bilimleri Enstitüsü, Bursa.

Bakker, J. P., Bridle, C. ve Timberlake, F. (1986). Tristimulus measurements (CIELAB 76) of portwine colour, Vitis,

\section{$25,67-78$}

Battle, I., Tous, J. (1997). Carob Tree (Ceratonia siliqua L.), International Plant Genetic Resources Institute. Via delle Sette Chiese, (142), 00145.

Benković, M., Bosiljkov, T., Semić, A., Ježek, D., ve Srečec, (2019). S. Influence of carob flour and carob bean gum on rheological properties of cocoa and carob pastry fillings. Foods, 8(2),66.

Bhattacharya, M., Zee, S.Y. ve Corke, H. (1999). Physicochemical properties related to quality of rice noodles. Cereal Chemistry, 76, 861-867

Chıllo, S., Laverse, J., Falcone, P.M., Nobıle, M.A.D. (2008). Quality of spaghetti in base amaranthus wholemeal flour added with quinoa, broad bean and chick pea. Journal of Food Engineering, 84, 101-107.

D’Egidio, M. G., Nardi, S. (1996). Textural measurement of cooked spaghetti, (Eds: J. E. Kruger, R. B. Matsuo and J. W. Dick), Pasta and noodles technology, St. Paul, MN: American Association of Cereal Chemists, 133156.

D’egidio, M.G., Stefanis, E.D., Fortini, S., Galterio, G., Nardi, S., Sgrulletta, D. \& Bozzini. A. (1982). Standardization of cooking quality analysis in macaroni and pasta products. Cereal Foods World, 27(8), 367-368.

Demir, B. (2008). Nohut Ununun Geleneksel Erişte ve Kuskus Üretiminde Kullanım Imkânları Üzerine Bir Araştırma, (Yayımlanmış Yüksek Lisans Tezi), Selçuk Üniversitesi, Fen Bilimleri Enstitüsü, Gıda Mühendisliği Anabilim Dalı, Konya

Durmuş, E., Yiğit, A. (2003). Türkiye'nin meyve üretim yöreleri. Fırat Üniversitesi Sosyal Bilimler Dergisi, Firat University Journal Of Social Science, 13(2), ,2354.

Ene, S. (2017). Kinoa'nın Erişte Üretiminde Kullanım Olanaklarının Araştırılması, (Yayınlanmış Yüksek Lisans Tezi), Çanakkale Onsekiz Mart Üniversitesi, Fen Bilimleri Enstitüsü, Çanakkale.

Eyidemir, E. (2006). Kayısı Çekirdeği Ilavesinin Eriştenin Bazı Kalite Kriterlerine Etkisi, (Yayınlanmış Yüksek Lisans Tezi), İnönü Üniversitesi, Fen Bilimleri Enstitüsü, Gıda Mühendisliği Anabilim Dalı, Malatya.

Fidan, H., Petkova, N., Sapundzhieva, T., Baeva, M., Goranova, Z., Slavov, A., ve Krastev, L. (2019). Carob Syrup and Carob Flour as Functional Ingredients in Sponge Cakes. Carpathian Journal of Food Science \& Technology, 11(1), 71-82.

Ginting, E., Yulifianti, R. (2015). Characteristics of Noodle Prepared from Orange- fleshed Sweet Potato and Domestic Wheat Flour, Procedia Food Science, 3: 289 $-302$

Gulia, N., Dhaka, V., Khatkar, B.S. (2014). Instant Noodles: Processing, Quality, and Nutritional Aspects, Critical Reviews in Food Science and Nutrition, 54(10), 13861399.

Gunathılake, K.D.P.P., ve Abeyrathne, Y.M.R.K. (2008). Incorporation of coconut flour into wheat flour noodles and evaluation of its rheological, nutritional and sensory characteristics. Journal of Food Processing and Preservation, (32), 2008, 133-142.

Köksel H, Sivri D, Özboy Ö, Baflman A, Karacan HD. (2000), Hacettepe Üniversitesi, Mühendislik Fak. Yayın No: 47, Hububat Laboratuarı El Kitabı. Ankara 
Köksel, H., Atlı, A., Özkaya, H. (1992). Bazı durum buğday çeşitlerinde yetiştirme yerinin elektroforetik özellikler ve makarna pişme kalitesi üzerine etkileri. Doğa-Turk J Agric For, 16(3): 593-605.

Köten, M. \& Ünsal, A.S. (2021). Mısır unu ilavesinin pandispanya tipi keklerin morfogeometrik, fonksiyonel ve tekstürel özelliklerine etkisi. Harran Tarım ve Gıda Bilimleri Dergisi, 25(2): 172- 184. DOI: 10.29050/harranziraat.850654

Köten, M., Ünsal, S. ve Atlı, A. (2014). Türkiye'de Üretilen Makarnaların Bazı Kimyasal Bileşimlerinin ve Pişme Kalitelerinin Belirlenmesi, Gıda Dergisi, 39 (1): 33-40.

Lai, H.M. (2001). Effects of Rice Properties and Emulsifiers on the Quality of Rice Pasta. Journal of the Science of Food and Agriculture, 82: 203-216.

Man, S., Páucean, A., Muste, S. and Mureşan, C. (2016). Influence of the different addition levels of buckwheat flour on pasta wheat flour, Bulletin UASVM Food Science and Technology, 73(1), 51-52.

Medjekal, S., Bodas, R., Bousseboua, H., ve López, S. (2018). Evaluation of Carob (Ceratonia siliqua) and Honey Locust (Gleditsia triacanthos) Pods as a Feed for Sheep. 8(2), 247-256

Papaefstathiou, E., Agapiou, A., Giannopoulos, S., ve Kokkinofta, R. (2018). Nutritional characterization of carobs and traditional carob products, Food science \& nutrition, 6(8), 2151-2161.

Pazır F., Alper Y. (2018). Carob Bean (Ceratonia siliqua L.) and Its Products.Anadolu Ege Tarımsal Araştırma Enstitüsü Dergisi, 28 (1), 108 - 112

Ritthiruangdej, P., Parnbankled, S., Donchedee, S., ve Wongsagonsup, R. (2011). Physical, Chemical, Textural and Sensory Properties of Dried Wheat Noodles Supplemented with Unripe Banana Flour. Kasetsart J. (Nat. Sci.) 45: $500-509$.
Rosa, C.S., Prestes, R.C., Tessele, K. ve Crauss, M. (2015). Influence of the different addition levels of amaranth flour and rice flour on pasta buckwheat flour, International Food Research Journal, 22(2), 691-698.

Şenay, F. (2009). Keçiboynuzundan Sıvı Şeker Üretimi, (Yayınlanmış Yüksek Lisans Tezi), Yıldız Teknik Üniversitesi, Fen Bilimleri Enstitüsü, İstanbul

Tunalıoğlu, R. ve Özkaya, M.T. (2003) Keçiboynuzu, Tarımsal Ekonomi Araştırma Enstitüsü- Bakış Dergisi, (3), 1-4.

Uzunoğlu, N., (2002). Erişte Kalitesini Etkileyen Bazı Faktörler, (Yayınlanmış Yüksek Lisans Tezi), Ankara Üniversitesi, Ankara

Wandee, Y., Dudsadee, U., Santhanee, P., Chureerat, P., Vilai, R., ve Nuanchawee, W. (2014). Enrichment of rice noodles with fibre-rich fractions derived from cassava pulp and pomelo peel. International Journal of Food Science and Technology, 49, 2348-2355.

Yağcı, S., Altan A., Göğüş, F. ve Maskan, M. (2006). Gıda Atıklarının Alternatif Kullanım Alanları, Türkiye 9. Gıda Kongresi, 24-26. Ankara

Yıldırım, A. \& Deger, Ö. (2021). Physical, physicochemical (technological) and chemical characteristics of common bread wheat (Triticum aestivum L.) varieties grown in Mardin region. Harran Tarım ve Gıda Bilimleri Dergisi, 25(2): 151-162. DOI: 10.29050/harranziraat.892966

Yılmaz, M. Y. (2009). Keçiboynuzu Suyu Üretim Teknolojilerinin Geliştirilmesi, (Yayınlanmış Yüksek Lisans Tezi), Yıldız Teknik Üniversitesi, Fen Bilimleri Enstitüsü, İstanbul.

Yüksel F., Akdoğan H. ve Çağlar S. (2018). Keten tohumu ile zenginleştirilmiş eriştelerin, fizikokimyasal, duyusal, pişme özellikleri ve yağ asidi kompozisyonunun belirlenmesi, The Journal of Food, 43(2), 222-230. 